\title{
Performance Based Compensation and Firm Value of Commercial Banks in Nigeria
}

\author{
Asian A Umobong $^{1 *} \quad$ Alabaraba Bele-Egberi ${ }^{2 *}$ \\ Department of Accounting, Faculty of Management Sciences, \\ University of Port Harcourt, Port Harcourt - Nigeria
}

\begin{abstract}
The study examined performance-based compensation and firm value using Secondary data obtained from Nigeria stock exchange and tries to ascertain the nature of relationship between bonuses and commission and value of firm measured by enterprise value, market capitalization and price to book ratio of commercial banks in Nigeria for the period 2012-2017. Findings indicate no significant relation between profit sharing and enterprise value, no significant relationship between profit sharing and market capitalization. Also, there is no significant relationship between bonuses and enterprise value and no significant relationship between bonuses and price to book ratio. Interestingly, we found significant relationship between bonuses and market capitalization and significant relationship between profit sharing and PBV. The moderating variables liquidity significantly negatively relate with market capitalization and insignificantly relate with PBV and enterprise value. Loan loss provisioning negatively and insignificantly relate with PBV and MCAP while also negatively and significantly relating with enterprise value. Interestingly result indicates that value of banks in Nigeria are driven by market conditions and factors external to compensation as pay does not motivate enough productivity to enhance value. This may be because of delayed promotion, job may not be enriched and meaningful, long hours of work, poor job security and poor job environment. These factors discourage commitment to long-term goal and interest of shareholders. Also, the low compensation- earnings ratio in banks may serve as a disincentive to high productivity hence the negative relation of pay and firm value. We recommend improved pay, job security, promotion and recreational facilities thus aligning with Hertzberg motivational theory
\end{abstract}

Keywords: Compensation, bonuses, profit sharing, Enterprise value, Market Capitalization, price to book value, Firm value

DOI: $10.7176 /$ RJFA/10-10-20

Publication date:May $31^{\text {st }} 2019$

\section{Introduction}

Firms are established to discharge responsibilities to the society and owners. Achievement of corporate objective are evaluated in terms of various performance measurement yardsticks.

Performance however is perceived to impact on firm value. To achieve this purpose intellectual and human capital play cardinal roles. However, the motivation and reward for employees to enhance performance has been a subject of controversy regarding the most appropriate model that should be adopted. Accomplishing overall firm alignment, mission, goals, objectives, pay and performance is cumbersome essentially because it requires aligning the corporate aspirations within firm structure with staff and providing motivations essential to goal accomplishment.

These motives drive organizations to attempt to develop compensation plans that will enable them to leapfrog the 21 st century competition and deliver wealth creation and value. The question agitating the mind of corporate Executives is if compensation programs are good for the firm and suppress employee morale. However, this depends on how effective the reward program supports the corporate goal or if the strategy encourages unhealthy competition and backstabbing by employees.

The controversy about the appropriate compensation and incentive program reverberates and is currently a subject of debate amongst Chief Executives, academics and practitioners. There is no simple and fast rule about the strategy and right compensation plan. To deal with this problem some chief Executives introduced personal incentives while others abolish bonus and incentive plans thus adopting opposing strategies. Yet others combine bonus and other incentives plans. Also, there is the perspective that instead of monetary rewards self-recognition and non-monetary rewards motivate higher than incentives and bonus plans.

Managers frequently are concern about how compensation plans affect wealth creation. Does the present pay structure motivate employees enough to be committed towards the goals of the firm such that it positively impacts on its earnings, wealth creation and firm value? The risk of poor remuneration and compensation is that if workers are demotivated and result in poor performance and the firm incurs losses, this will cause greater volatility in earning and therefore greater volatility in the stock price and such firm may not be able to pay any dividend to its ordinary stockholders as it preferred security holders rank higher than ordinary shareholders.

Also, the lack of consensus by empirical studies on effective reward program creates gap for further studies. Furthermore, most empirical studies focus on executive compensation which form a small portion of employee 
cost while ignoring pay sensitivity of other staff which influences performance, firm value, and shareholders wealth. Other studies focus on executive pay, conflict of interest and earnings management without looking at other employees being the goose that lay the golden egg. This study therefore is a departure as it focuses on employee motivation through performance-based compensation, and firm value. In sub Saharan Africa and in Nigeria, there is paucity of research on how employee compensation translates to firm value.

Many Nigeria Firms are adopting performance-based compensation strategy for enhancing corporate performance, yet there is no empirical study to our knowledge in Nigeria that has captured the effect of performance-based compensation on firm value. This study bridges this gap. The aim of the study is to ascertain the nature of relationship between performance-based compensation and firm while the objectives is to determine how bonuses and profit sharing relate with market capitalization, price to book ratio and enterprise value.

\subsection{Theoretical Framework}

Motivational theories form the bedrock of compensation as managers attempt to deploy various strategies in meeting corporate goal. It is believed that motivation plays important role in performance by employees. Based on this we consider three motivational theories and its various proposition in influencing compensation plans as a sin qua-non-for corporate performance and the role conflict of interest can play in affecting performance positively or negatively.

\subsubsection{Herzberg's Two-Factor Theory of Motivation}

The two-factor theory, known as motivator hygiene theory was proposed by Frederick Herzberg in 1959. Herzberg recognized that satisfaction in work place are caused by satisfiers while non-satisfiers cause dissatisfaction. These factors are opposite thus Herzberg further postulated that opposite of "Satisfaction" is "No satisfaction" and of "Dissatisfaction" is "No Dissatisfaction. Herzberg categorized the job factors into hygiene and motivational factors- Hygiene factors are recognized as necessary for motivation in the work place but does not lead to long term satisfaction although its absence or non-existence in the work place will cause dissatisfaction. Hygiene factors basically are not motivators. This imply that adequacy of hygiene factors in a typical work environment pacify workers and prevent dissatisfaction. Herzberg further stated that hygiene (dissatisfies or maintenance factors are extrinsic to work and helps to avoid dissatisfaction. They are basically psychological needs which individuals crave and expect to be satisfied and is centered on the job environment and scenario.

Linked to the hygiene factors are the attributes that the compensation or pay structure is expected to be competitive within same industry, appropriate and reasonable. The firm policies and administration should be flexible not rigid, fair, and equitable. Such as flexible work hours, breaks, vacation, good health care plan, vacations and dress code. Good physical working conditions such as Safety in the work place, clean and hygienic work place, functional equipment. The firm should also encourage good interpersonal relation amongst employees, peers, superiors and subordinates. Employees should be offered job security. Herzberg further postulated that motivational factors known as satisfiers provide positive satisfaction and are necessary for work while motivating employees to superior performance and goal accomplishment. It is believed motivational factors provide intrinsic reward while also symbolizing psychological needs perceived as additional benefit to employees. Examples of motivational factors are:

a) Recognition - When employees achieve specific goals should be praised and recognized for these accomplishments by managers.

b) Sense of achievement - Employees should possess sense of achievement. This is a function of the job.

c) Growth and promotional opportunities - Growth and advancement opportunities should be created as a motivation for employees to work well.

d) Responsibility -Employees should hold themselves accountable for the job with a sense of responsibility to carry out assigned duties. Managers on the other hand are expected to transfer ownership of the job to employees by reducing control while retaining accountability.

e) Meaningfulness of work - Work itself should be meaningful, interesting and challenging for the employee to perform and to get motivated.

\subsubsection{Maslow's Hierarchy of Needs Theory}

The theory was proposed by Abraham Maslow in1943 and it depicts human motivation was based on the proposition that human needs vary and in hierarchy of five within everyone. The basic human needs are classified from bottom as physiological, safety, social, esteemed and self-actualization Physiological needs being the need for basic amenities such as include need for air, water, food, clothing, and shelter. Safety needs imply that human's beings require physical, environmental, emotional safety, and protection. An employee requires job security, financial security, protection from animals, family security, health security. Social needs- Social needs encompasses need for love, affection, care, belongingness, and friendship. Esteem needs-These needs can be categorized into internal and external esteem needs. The internal esteemed needs include self- respect, confidence, competence, achievement and freedom while external esteem needs are recognition, power, status, attention, and admiration. Self-actualization need- People aspire and ought to become what they can become. The urge to 
actualize the potential is what is referred to as self-actualization. It embodies the desire for growth and selfcontentment.

It also encompasses the need to increase knowledge, social- service, creativity and innovations. Selfactualization needs are never fully accomplished. As an individual mature psychologically, opportunities are created and become more visible and the desire for self-growth and enhancement continues to rise. According to the theory motivation result from unachieved needs and once a need or desire has been accomplished; a new one emerges as a product of the inertia that drives the earlier need. Maslow in his propositions classified the five human needs into Higher and Lower order needs. Physiological and safety needs are the lower-order needs and are met externally. Social, esteem, and self-actualization needs are grouped under higher-order needs which are achieved internally, within the individual. Thus, we conclude during boom period, employees lower level needs are significantly met.

\subsubsection{Expectancy Theory}

Expectancy theory of motivation was propounded by Victor Vroom in 1964. He laid emphasize on outcomes rather than needs which is a departure from prior theories proposed by Maslow and Herzberg. The postulation is that the tendency of performance in a specific fashion is a function of intensity of an expectation that performance will be accompanied by definite outcome and appeal of the outcome to those concern. ETM specifies that motivation is produced from expectation of an individual as reward (Valence), the evaluation that the probability that effort will produce expected performance (Expectancy) and belief that performance will produce reward (Instrumentality). In summary, Valence is the importance accorded by an individual about expected output. The theory assumes that employees knowingly decide to perform or not to perform a specific job depending on level of individual motivation. This chronologically depends on the expectancy, Valence and instrumentality. Expectedly some authors support the theory while other pick holes on the assumptions and propositions contained in the theory.

Supporters of the theory argue that the theory encourages self-centered individuals aim to maximize satisfaction, minimize dissatisfaction, encourages psychological extravagance with the motive to attain pleasure and minimize pain while being rewarded and compensated. The individual focus on expectation and perception ignoring reality. However, those opposed to the theory argue that reward more often does not correlate performance but rather position, effort, education and responsibility. In managing employees, the theory suggest that managers can relate the expected outcome with performance level and ensure that employees achieve expected performance level. It encourages the design of reward commensurate with performance. It emphasized appropriate job design, fairness and continuous assessment of employee motivation level as a prerequisite for motivating employees for achievement of high productivity.

\subsection{Conceptual Framework}

\subsubsection{Compensation}

Compensation is often perceived from the view point of deriving pay or being rewarded for work done, energy and time expended which could be through full or part time work engagement.

Employers look at compensation as pay to employees as reward for work performed and require that employees should plan for it in a systematic manner. The employee and employers must agree to avoid differences in perception which may create conflicts and dissatisfaction which may mar or cause friction in relationship. Compensation binds the employee and employer together through contracts or a mutually conceived legal document that articulates the terms of engagement and specifies the pay and other components of the compensation package.

From Maslow's Need Hierarchy Theory, compensation is a basic motivator found at the lower rung of ladder while job satisfaction, and fulfilment is at a higher level. It is therefore cogent that appropriate quantification of employee's contributions to achievement of corporate goal is documented and the employee adequately compensated as this can assist in making employees put in their best to work.

Monetary compensation exchanged for work executed forms the basis of compensation and proper management through processes, procedures and systems is an essential aspect of compensation management. Compensation management is an essential tool in leapfrogging competition and retaining talent. The 21 st century employee is being assessed as creators and drivers of value instead as factor of production.

Firms globally are conscious of the compensation paid to employees, pay structure, and whether the right compensation and opportunities when provided by the firms make work enjoyable to employees and manager's task made simpler leading to satisfaction by both employee and employer. The theory argues that it is essential to provide hygiene factors to prevent dissatisfaction.

The argument is advanced that a fair and just reward when provided ensures that the individual advances to higher level need like job satisfaction and fulfilment. In contrast, the absence of hygiene factors can cause unhappiness and demotivation with the attendant consequence of attrition and associated negative outcome.

\subsubsection{Performance based Compensation}

Performance compensation plans assert difference between ordinary and extraordinary performance that merits a 
distinct difference in compensation. Pay for-performance assist firms to increase or strengthen the link between rewards and performance outcomes that makes good economic sense and rewards those who help the organization excel.

Performance compensation plans can allow entities to use pay on the achievement of certain improvements in corporate performance as well as overall employee effectiveness. Articulated goals, purposefulness, increase individual, group and overall enterprise accountability. Managers are constantly faced with the decision of choosing a compensation policy which is the most crucial decisions a firm can make.

Recently, some employers adopted pay-for-performance model, by providing financial rewards to employees who meet and surpass performance expectations. Analysts have observed advantages and drawbacks to this method of determining employee pay as employees frequently expect wage increases when job role has not changed.

Many firms offer automatic salary increase during annual performance review. While some others no longer provide pay raise to employees just for being at work. Instead, workers are compensated with pay raise when performance targets are achieved or exceed. Pay-for-performance models vary, but its major feature is provision of guidelines of the form of expectation employees should have about pay increase at each standard performance level. An instance is the case that the firm may not give pay rise to poorly performing staff during performance appraisals or the bottom-line ten percent of the work force during appraisal exercise for each category of staff could be asked to exit. Additional as a performance model top performer or employees with excellent evaluations are rewarded with promotion or additional pay increase called notch when not promoted or those employees who have excellent reviews would receive the highest raises. Today's pay-for-performance models essentially reinforces and adopt Victor Vroom's expectancy theory (1964) of motivation and management. The theory specifies that individuals have diverse goals and will accomplish them if they believe and sufficiently motivated to attain, thus implying a positive correlation between efforts and performance. Sterling performance will ultimately produce desirable reward.

The urge to satisfy the need if channeled to efforts and is strong enough will fulfill expected result thus making the effort worthwhile. To accomplish the level of motivation, Vroom suggest an in-depth examination of each component and performance outcome needed to achieve organization's aspired level of performance. This makes pay-for-performance focused on outcomes far superior to tasks.

Individuals crave for trust and desires to be valued for outcomes achieved that go beyond tasks that comprise achievement. This desire can be leveraged to improve performance exponentially. A good performance-based compensation system links pays and performance and must also incorporate measures that clearly distinguish between ordinary and extraordinary performance. What drives performance therefore is the theory that rewards, and bonuses motivate employees to perform better.

\subsubsection{Firm Value}

In determining a firm's Value according to Biggs (1978), stock price sometimes, is the sole measure of performance considered by the interested party. More commonly it is a major component of a weighted average that includes other measure. Firm value is achieved through different measures, each of which produces different valuations.

The first measure of firm value is its accounting net worth or book value. This measure is however problematic, because the accounting rule in a model may vary (in divergence) with generally accepted principles of financial accounting. This is because adherence to some generally accepted principles such as historical cost and conservatism can lead to values that are far from what is reasonable.

The second measure is market value of its outstanding shares. This is a well-known technique of valuation of quoted firms. However, the adoption of the technique requires an efficient market for shares. This condition is not met in models that do not allow participants to trade shares, and even when such trading is allowed, the trades are generally too few and too infrequent for reliable valuation. The third measure capitalizes value of projected future performance.

Modigliani \& Miller (1961) pointed out that though four distinct method of capitalization can be applied to value a firm, all four-give rise to precisely the same valuation when the markets are perfect. The fourth measure is the deductive application of human judgment. With this method, firms are rated along a psychometric scale. The results are then converted by formula to monetary values. The problem of this measure is that it requires subjective judgment. The fifth measure is the firm's accounting net worth adjusted for intangible and idiosyncrasies of accounting rules used in the simulation. Although principle could be laid out for the adjustment, the specific principle must depend upon the model.

The market value measure of determining firms' value is reliable and straightforward way of determining a firm's value, it is known as market capitalization i.e. total value of all shares outstanding. This method only works for publicly traded companies, were shares value can be easily determined. The market capitalization (market value) of a firm is determined by multiplying number of outstanding shares by the current stock price. Market capitalization does not depict firm's value because it ignores salient factors, such as debt and cash reserves. To 
circumvent this anomaly enterprise value method is adopted. Enterprise Value (EV) or total value, is a comprehensive alternative to equity market capitalization.

\subsection{Empirical Review}

Duru \& Iyengar (2001) explore the relationship between compensation variables and accounting- and marketbased performance measures. Their evidence shows that bonuses are more closely tied to accounting performance measures like earnings before interest and taxes (EBIT) and earnings per share.

Brickley, Bhagat \& Lease (1985)) present empirical evidence indicating that stock prices respond favorably to the adoption of, or changes to, performance-based compensation plans. Some empirical evidence buttresses the hypothesis that performance-based compensation modifies management's investment decisions in ways to cause improvement in shareholder wealth (Amihad \& Lev,1981; Larker, 1983).

Lazear (2004) suggests that performance-based pay may serve less as a motivational device and more as tool for sorting, to screen effective managers and retain productive staff. Waller \& Chow (1985) show that managers select among alternative compensation contracts based on ability and the correlation between ability and incentives.

Cadsby, Song \& Tapon (2007) found that pay-for-performance contracts result in higher performance through both sorting and incentive effects. They find that highly skilled managers select and encourage performance-based pay contracts and that such contracts lead to greater productivity regardless of skill level. This ultimately impact firm value.

Blanchflower, Oswald, \& Sanfey (1996) find a performance elasticity of 0.08 firms in USA both suggesting significant positive association of pay for performance with firm value. Smith \& Watts (1992) observed positive relation of firm growth and incentive pay.

Prior research by Banz (1981) and Amihud \& Mendelson, (1986) suggests a correlation of firm size, liquidity risk and firm value. In theory, liquidity can impact decision making by the firm.

Brown \& Peterson (2011) suggest that innovations by firm increases risk and uncertainty but proper liquidity management provides financial flexibility to mitigate this risk. Jonathan (2003) explain that a relation exists between firm liquidity and innovation.

Holmstrom \& Triole (2000) find that firms can reduce potential risk and increase firm value by holding appropriate level of liquidity. Du,J; Wu, F\& Liang, (2016) found Liquidity is positively significantly related to firm value.

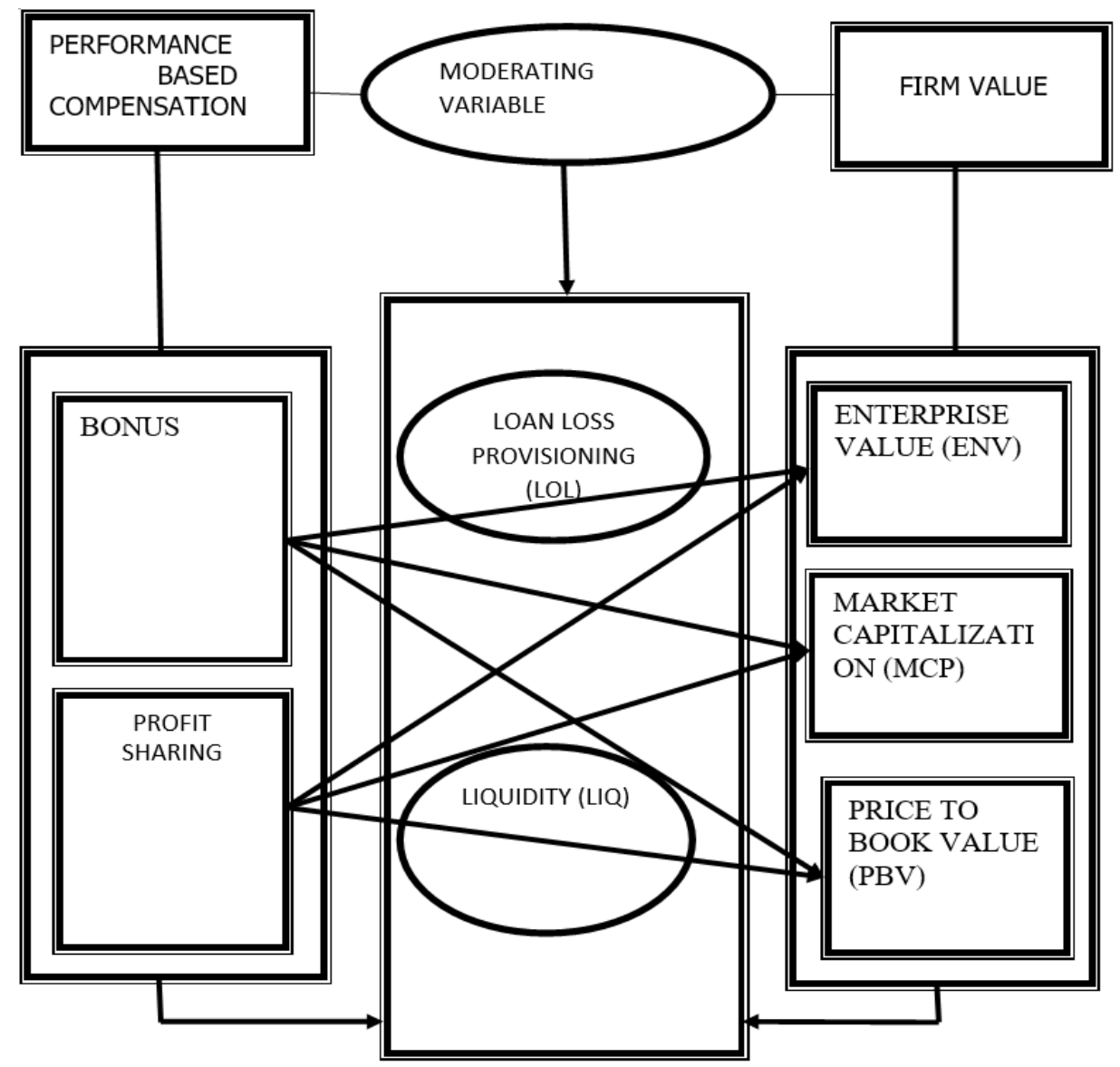

Authors's conceptualized Framework of Performance based compensation and Firm value 


\section{Materials and Method \\ Data}

Data for the study is mainly secondary data sourced from Nigeria Stock Exchange and firm's website. This study used the cross-sectional survey ex-post facto design and examined firms or subjects' annual financial reports and obtained data directly from firms under study through direct request. The quasi experimental design required examination of the interrelationship among variables using panel data obtained from the NSE from a cross section of commercial banks listed in Nigeria for the period 2012 to 2017. The data is ex-post facto because it is secondary data and relies on past events. The study adopted census sampling method. However, census sampling method do not require any sampling, so no method was used in determining sample size. Only firms for which data are available over the entire sample period for all the variables are included in the final samples. The sample data are six years of unbalanced cross-sectional panel data spanning from 2012 to 2017 for all the commercial banks using performance-based compensation strategy.

\section{Variables}

Dependent Variable

Dependent variables include in both absolute terms (Enterprise value, market capitalization) and relative terms (price to book ratio)

\section{Enterprise value (ENV):}

Following Dhankar \& Boora (1996); Chadha \& Sharma (2016) and Aggrawal \& Pahdan (2017) we adopt Enterprice value as a proxy for firm value.

Market capitalization (MCP) Following Dhankar \& Boora (1996), and Chadha \& Sharma (2016) and Aggrawal\& Pahdan (2017) we use market capitalization as a proxy for firm value because this metric is devoid of debt and reflects how much the equity of the firm is priced in the market in absolute terms Price to Book (PBV) Following Ozkhan (2002), Antoniou, Bevan \&Chuang (2008) and Pruitt (1994) we use PBV as proxy for relative firm value. It shows the ratio of market price of equity and its book value. A higher than 1 ratio means that market has priced its equity more than its book value.

\section{Independent Variables}

The independent variables in the study are bonuses and profit sharing which payments are made to employees based on performance.

Bonuses- This imply total bonuses earned by employees because of performance in a year. To measure the sensitivity of such income relative to earnings we deduct previous year bonus from current year bonus year bonus and divide the outcome with changes in PBT of current year when compared to PBT of previous year.

Profit Sharing: These are payments made to employees as a percentage of profit before tax and are mainly paid after the declaration of profit and Annual General meeting for approval of accounts and declaration of dividend. We proxy it as total Profit shared to staff in a particular financial year. To measure sensitivity, we include changes in profit shared to staff divide by changes in Profit before tax

\section{Moderating Variable}

The moderating variables for this study are:

\section{Liquidity}

As a factor liquidity can impact on performance and influence firm value especially for financial institutions which is a subject of our study. With high liquidly firms can finance short term investments with ease and meet maturing obligations. Dependent upon industry characteristics, various empirical studies give mixed results on impact of liquidity on firm value.

We expect a significant relation between liquidity and firm value. We proxy liquidity using current asset ratio:

\section{Loan Loss provisioning}

The level of bad loans in a particular financial year will impact firm value. We proxy this as bad loans written off divide by total portfolio of bad loans

\section{Test and selection of model}

The study deploys panel data which combines time and cross-sectional series data obtained from a cross section of individual data observed at varied times. The two-paneling method used by Generalized Least square (GLS) to choose the most suitable model for testing is Fixed Effect Model (FEM) and Random Effect Model (REM).

\section{Hausmann Test}

HT is a method use in selecting between two alternatives; fixed and random effects. The criteria are that random effect is a null hypothesis while fixed effect is the alternate. The test follows a statistical distribution chi square with degree of freedom as many as $\mathrm{K}$. K represents number of independent variables. When the null form is rejected where the value of statistics is greater than critical value (the value of the table chi square) then fixed effect is utilized conversely reject fixed effect and accept random effect. 


\subsection{Model Specification}

The econometric model between the dependent and independent variable, the disturbance, co-efficient and intercepts for performance-based compensation and firm value for the research is as stated below:

$\mathrm{ENV}=(0+(1 \mathrm{Bon}+(2 \mathrm{Psh}+(3 \mathrm{Lol}+(4 \mathrm{Fms}+(5 \mathrm{Liq}+\mathrm{U} 1, \mathrm{t}-(\mathrm{i})$

$\mathrm{MCP}=(0+(1 \mathrm{Bon}+(2 \mathrm{Psh}+(3 \mathrm{Lol}+(4 \mathrm{Fms}+(5 \mathrm{Liq}+\mathrm{U} 1, \mathrm{t}-(\mathrm{ii})$

$\mathrm{PBV}=(0+(1 \mathrm{Bon}+(2 \mathrm{Psh}+(3 \mathrm{Lol}+(4 \mathrm{Fms}+(5 \mathrm{Liq}+\mathrm{U} 1, \mathrm{t}(\mathrm{iii})$

Where Bon is bonus, Psh is Profit sharing, Lol is loan loss provisioning Liq is liquidity, Fms is firm size. On the other hand, Env is enterprise value, MCP is market capitalization and PVB is price to book value while: Ui,t $=$ Error term $(0,=$ intercepts $(1=$ slope coefficients from equations, $i$ to iii, it is expected $1>0$. It is also expected that an increase in bonuses, profit sharing, and liquidity will increase firm value

\subsection{RESULT AND DISCUSSION OF FINDINGS \\ 4.1 RESULTS \\ DESCRIPTIVE STATISTICS}

Table 4.1. Descriptive Statistics

\begin{tabular}{|l|c|c|c|c|c|c|c|}
\hline & Mean & Max & Min & Std. Dev. & Jarque-Bera & Prob & Obs \\
\hline BON & 0.019273 & 0.025 & 0.0145 & 0.002649 & 1.618507 & 0.44519 & 30 \\
\hline PSH & 0.025 & 0.03 & 0.02 & 0.003216 & 0.3125 & 0.8553 & 30 \\
\hline LOL & 0.246912 & 0.718841 & 0.010915 & 0.175793 & 5.539218 & 0.0626 & 30 \\
\hline LIQ & 0.48854 & 0.6 & 0.0085 & 0.106377 & 228.7506 & 0.000 & 30 \\
\hline ENV & 0.207604 & 1.832376 & 0.027271 & 0.356434 & 266.4938 & 0.000 & 30 \\
\hline MCP & 26.56037 & 27.81278 & 25.51283 & 0.695092 & 2.200102 & 0.332 & 30 \\
\hline PBV & 0.368667 & 1.820194 & $5 \mathrm{E}-07$ & 0.52934 & 7.010281 & 0.0300 & 30 \\
\hline
\end{tabular}

Source: Researcher's compilation (2019)

The descriptive statistics of the data is presented in table 4.1 above. As observed, BON has a mean value of 0.0192 with maximum and minimum values of 0.025 and 0.0145 respectively. The standard deviation is also low at 0.003 which indicates considerable clustering of BON around the mean. PSH has an average value of 0.025 with maximum and minimum values of 0.03 and 0.02 respectively and the standard deviation of 0.003 suggest considerable dispersion from the distribution mean. The average LOL is 0.2469 with maximum and minimum values of 0.7188 and 0.0109 respectively with a standard deviation of 0.1757 . The average LIQ is 0.4885 with maximum and minimum values of 0.6 and 0.0085 respectively with a standard deviation of 0.1063 . As observed, ENV has a mean value of 0.2076 with maximum and minimum values of 1.8323 and 0.00272 respectively. The standard deviation is at 0.356 . MCAP has an average value of logged value of 26.560 with maximum and minimum values of 27.812 and 25.5128 respectively. PBV has mean value of 0.368 and maximum and minimum values of 1.8201 and 0.000 .

4.1.2 TEST OF NORMALITY

Table 4.2: Residual Normality

\begin{tabular}{|c|c|c|c|c|c|c|c|c|c|c|}
\hline \multicolumn{11}{|l|}{20} \\
\hline \multirow[b]{3}{*}{16} & & & & & & & & & \multirow{3}{*}{\multicolumn{2}{|c|}{$\begin{array}{l}\text { Series: Standardized Residuals } \\
\text { Sample } 20122017 \\
\text { Observations } 30\end{array}$}} \\
\hline & & & & & & & & & & \\
\hline & & & & & & & & & & \\
\hline \multirow[t]{3}{*}{12} & & & & & & & & & Mean & $-1.04 \mathrm{e}-16$ \\
\hline & & & & & & & & & Median & -0.098707 \\
\hline & & & & & & & & & Maximum & 1.311990 \\
\hline \multirow[t]{2}{*}{8} & & & & & & & & & Minimum & -0.329047 \\
\hline & & & & & & & & & Std. Dev. & 0.292532 \\
\hline \multirow{2}{*}{4} & & & & & & & & & Skewness & 3.094856 \\
\hline & & & & & & & & & Kurtosis & 14.62160 \\
\hline $0 \Perp$ & & & & & & & & & Jarque-Bera & 216.7177 \\
\hline-0.50 & -0.25 & 0.00 & 0.25 & 0.50 & 0.75 & 1.00 & 1.25 & 1.50 & Probability & 0.000000 \\
\hline
\end{tabular}

Source: Researcher's compilation (2019)

Table 4.2 shows the normality test for the standardized residuals. When the observations are not normally 
distributed, the associated normal and chi-square tests are inaccurate and consequently the $\mathrm{t}$ and $\mathrm{F}$ tests are not generally valid in finite samples. However, they have an asymptotic justification. Koenker (1982) pointed out that the power of $\mathrm{t}$ and $\mathrm{F}$ tests is extremely sensitive to the hypothesized distribution and may deteriorate very rapidly as the distribution becomes long-tailed. Furthermore, Bera and Jarque (1982) have found that homoscedasticity and serial independence tests suggested for normal observations may result in incorrect conclusions under nonnormality. The Jacque-bera statistics of 216.7177 and p-value of 0.00 confirms the normality of the residuals and the absence of outliers.

\subsubsection{PEARSON CORRELATION ANALYSIS}

Table 4.3. Pearson Correlation Analysis

\begin{tabular}{|c|c|c|c|c|c|c|c|}
\hline & $\mathrm{BON}$ & PSH & LOL & LIQ & ENV & PBV & MCCAP \\
\hline $\mathrm{BON}$ & 1 & & & & & & \\
\hline PSH & -0.2226 & 1 & & & & & \\
\hline LOL & 0.081328 & 0.022137 & 1 & & & & \\
\hline LIQ & 0.240278 & -0.10225 & 0.204578 & 1 & & & \\
\hline ENV & -0.03664 & -0.19528 & -0.52809 & -0.20225 & 1 & & \\
\hline PBV & 0.233784 & -0.39671 & -0.08961 & 0.279599 & 0.113452 & 1 & \\
\hline MCCAP & -0.10755 & 0.011161 & -0.10144 & -0.25237 & 0.036159 & 0.259075 & 1 \\
\hline
\end{tabular}

Source: Researcher's compilation (2019)

From table 4.3, the correlation coefficients of the variables are examined. However, of particular interest to the study is the correlation between the dependent variables (MCCAP, PBV and ENV) and the independent variables. As observed, MCCAP is negatively correlated with BON ( $\mathrm{r}=-0.108)$, LOL $(\mathrm{r}=-0.1012)$, LIQ $(\mathrm{r}=-0.2523)$ and positively with PSH $(\mathrm{r}=0.111)$. As observed, ENV is negatively correlated with $\mathrm{BON}(\mathrm{r}=-0.036), \mathrm{LOL}(\mathrm{r}=-$ $0.52809)$, LIQ $(\mathrm{r}=-0.2023)$ and with PSH $(\mathrm{r}=-0.1952)$. PBV is positively correlated with BON ( $\mathrm{r}=0.2337)$, LIQ $(\mathrm{r}=0.2796)$ and negatively with PSH $(\mathrm{r}=-0.3967)$ and LOL $(\mathrm{r}=-0.059)$. Though providing some level of insight into the degree and direction of relationship between the variables, the correlation analysis is limited in its inferential ability mainly because it does not imply functional dependence and hence causality in a strict sense and regression analysis is better suited for this purpose.

4-1.4 VARIANCE INFLATION FACTOR TEST

Table 4.4 Variance Inflation Factor Test

\begin{tabular}{|c|c|}
\hline Variable & VIF \\
\hline PSH & 1.35 \\
\hline BON & 1.17 \\
\hline LIQ & 1.11 \\
\hline LOL & 1.05 \\
\hline
\end{tabular}

Source: Researcher's compilation (2018)

The variance inflation factor (VIF) explains how much of the variance of a coefficient estimate of a regressor has been inflated, because of collinearity with the other regressors. Essentially, VIFs above 10 are a cause of concern as observed, none of the variables have VIF's values more than 10 and hence none gave serious indication of multicollinearity. 


\subsubsection{REGRESSION RESULT}

Table 4.5. Panel Regression Result

\begin{tabular}{|c|c|c|c|c|}
\hline Variable & $\begin{array}{l}\text { Aprori } \\
\text { Sign }\end{array}$ & PBV & ENV & MCAP \\
\hline$C$ & & $\begin{array}{c}0.8673 \\
(0.7326) \\
\{0.236)\end{array}$ & $\begin{array}{c}1.2324^{*} \\
(0.3329) \\
\{0.000\}\end{array}$ & $\begin{array}{c}27.8830^{*} \\
(2.7183) \\
\{0.000\}\end{array}$ \\
\hline PSH & + & $\begin{array}{c}-56.6108^{*} \\
(12.9275) \\
\{0.0000\}\end{array}$ & $\begin{array}{c}-22.0496 \\
(14.4881) \\
\{0.128\}\end{array}$ & $\begin{array}{c}2.7438 \\
(108.383) \\
\{0.980\}\end{array}$ \\
\hline BONUS & + & $\begin{array}{c}21.8507 \\
(32.9201) \\
\{0.507\}\end{array}$ & $\begin{array}{l}-1.6284 \\
(6.1194) \\
\{0.790\}\end{array}$ & $\begin{array}{c}-18.1858 * \\
(5.7895) \\
\{0.002\}\end{array}$ \\
\hline$L O L$ & + & $\begin{array}{c}-0.4259 \\
(0.2532) \\
\{0.093\}\end{array}$ & $\begin{array}{c}-1.01102 \\
(0.2642) \\
\{0.000\}\end{array}$ & $\begin{array}{c}-0.17909 \\
(0.1261) \\
\{0.155\}\end{array}$ \\
\hline$L I Q$ & + & $\begin{array}{c}1.2295 \\
(0.7778) \\
\{0.114\}\end{array}$ & $\begin{array}{c}0.3943 \\
(0.6086) \\
\{0.517\}\end{array}$ & $\begin{array}{c}-1.5302 \\
(0.5653) \\
\{0.007\}\end{array}$ \\
\hline$R^{2}$ & & 0.2438 & 0.326 & 0.0734 \\
\hline Adjusted $R^{2}$ & & 0.2051 & 0.301 & 0.0039 \\
\hline Wald -chi 2(4) & & 4095.22 & 313.97 & 1.1662 \\
\hline Prob & & 0.000 & 0.000 & 0.3222 \\
\hline \multicolumn{5}{|l|}{ Model Diagnostics } \\
\hline Hausman & & 0.7125 & 0.672 & 0.829 \\
\hline \multicolumn{5}{|c|}{ Diagnostics for cross-sectional dependence } \\
\hline Frees Test & & 0.202 & 0.190 & 0.282 \\
\hline Friedman test & & 0.689 & 0.402 & 0.622 \\
\hline Peaseran Test & & 0.8180 & 0.840 & 0.798 \\
\hline L.M test for Hetero & & 0.182 & 0.679 & 0.391 \\
\hline Ramsey Reset test & & 0.410 & 0.8721 & 0.120 \\
\hline Mean VIF & & & 1.22 & \\
\hline \multicolumn{5}{|c|}{ Sensitivity Test for Endogeneity: } \\
\hline Wu-hausman test (BON) & & $=0.11514 \mathrm{~F}(1,24)$ & $\mathrm{P}$-value $=0.73732$ & \\
\hline Wu-hausman test (PSH) & & $=0.07608 \mathrm{~F}(1,24)$ & $\mathrm{P}$-value $=0.78504$ & \\
\hline $\begin{array}{l}\text { Sargan statistic p-value } \\
\text { (over-identification test) }\end{array}$ & & 0.2881 & & \\
\hline
\end{tabular}

Source: Researchers compilation (2019)

The regression results examine the relationship between compensation measures (BON and PSH) on firm market value measured by ENV, PBV and MCCAP. Table 4.4 show the regression results of the Random effects (RE) estimation selected based on the Hausman test. The $\mathrm{R}^{2}$ for the PBV model is about $24 \%$ with a significant Wald-chi statistic which suggest that the hypothesis of a significant linear relationship between the dependent and independent variables cannot be rejected. It is also indicative of the joint statistical significance of the model. The analysis of coefficients reveals that of the two measures of compensation examined, PSH is significant $(p=0.000)$ but negative (-56.61) and this implies that PSH has a significant negative impact on PBV. The control variables of LOL and LIQ were statistically insignificant at 5\%. The $\mathrm{R}^{2}$ for the ENV model is about $32.6 \%$ with a significant Wald-chi statistic. The analysis of coefficients reveals that none of compensation measures examined turned up significantly $(\mathrm{p}=0.000)$. The control variable LOL showed statistical significance at $5 \%$. \%. The $\mathrm{R}^{2}$ for the MCAP model is the lowest of the three at $7.3 \%$ which suggest that compensation measures appear very inadequate in accounting for systematic variations in MCAP and this may be expected as capitalization is market activity driven. The analysis of coefficients reveals that BON is statistically significant $(\mathrm{p}=0.002)$ though with a negative beta (18.185). The control variable liquidity showed statistical significance at $5 \%$.

The diagnostics results reveal that the presence of cross-sectional dependence in the residuals is unlikely as all test conducted (frees, Friedman and Peaseran) all confirmed the hypothesis of no cross-sectional dependence in the residuals with p-values above 0.05. Again, the L.M test for heteroskedasticity was also conducted and the $\mathrm{p}$-value indicates that the null hypothesis of homoscedastic errors is confirmed. The Ramsey reset test for model specification confirms that correct functional form specifications of the models. The suspicions of simultaneity in the compensation- firm value nexus which may bias the result from an endogeneity stand-point necessitated the 
need for endogeneity test to be conducted for the compensation variables to ascertain the presence or otherwise of endogeneity. The Wu-Hausman test for was performed and the results showed that both BON and PSH are exogenous variables and thus the estimation do not suffer from endogeneity bias. The saran test confirms the validity of the instruments and confirms over-identification status. On the overall, the effect of compensation on firm value has depicted quite low $\mathrm{R}^{2}$ across the measures of firm value adopted in the study and this suggest that several other factors are integral in the determination of firm value rather than just compensation. The betas also appear sensitive to the measures of firm value being utilized.

\subsection{Hypotheses}

HO1: There is no relation significant between profit sharing and Enterprise value?

From the Hausmann test result on table 4.5 above, p-value is $0.672>0.05$. We accept the assumption that random effect model is more appropriate in assessing the relationship between profit sharing and enterprise value. Therefore, we adopt Random effect model (REM) in determining the relationship between Profit sharing (PSH) and Enterprise value. From table 4.5, regression of PSH on ENV showed an intercept of 1.2324 and co-efficient 22.0496 and $p$-value of $0.128>0.05$. Based on p-value, we accept the hypothesis that there is no significant relationship between profit sharing and enterprise value. The negative co-efficient indicate that an increase in profit sharing reduces the enterprise value of the firm. The determination co-efficient is 1.2324 which implies that the variation in profit sharing explains $12 \%$ of the variation in enterprise value of the firm.

HO2: There is no relation significant between profit sharing and Market capitalization?

From the Hausmann test result on table 4.5 above, p-value is $0.829>0.05$. We accept the assumption that random effect model is more appropriate in determining the relationship between profit sharing and enterprise value. Therefore, we adopt Random effect model (REM) in assessing the relationship between Profit sharing (PSH) and Enterprise value. From table 4.5 regression of PSH on MCAP showed an intercept of 27.8830 and co-efficient 2.7438 and $p$-value of $0.980>0.05$. Based on $p$-value we accept the hypothesis that there is no significant relationship between profit sharing and market capitalization. The positive co-efficient indicate that an increase in profit sharing increases market capitalization value of the firm. The determination co-efficient is 27.8830 which implies that the variation in profit sharing explains $28 \%$ of the variation in market capitalization as a measure of firm value.

HO3: There is No relation significant between profit shared and Price to book value?

From the Hausmann test result on table 4.5, p-value is $0.7125>0.05$. We accept the assumption that random effect model is more appropriate in assessing the relationship between profit sharing and price to book value. Therefore, we adopt Random effect model (REM) in determining the relationship between Profit sharing (PSH) and PBV. From table 4.5 above, regression of PSH on PBV showed an intercept of 0.8673 and co-efficient -56.6 and P-value $0.000<0.05$. Based on $\mathrm{p}$-value, we reject the hypothesis that there is no significant relationship between profit sharing and PBV. This implies that profit sharing impacts PBV value significantly. The negative co-efficient indicate that an increase in profit sharing reduces PBV. The determination co-efficient is 0.87 which implies that the variation in profit sharing explains $8 \%$ of the variation in PBV.

HO4: There is no relation significant between Bonuses paid and Enterprise Value

From the Hausmann test result on the regression table 4.5, p-value is $0.672>0.05$. We accept the assumption that random effect model is more appropriate in assessing the relationship between bonuses and enterprise value. Therefore, we adopt Random effect model (REM) in determining the relationship between bonuses (BON) and Enterprise value. From table 4.5, regression of BON on ENV showed an intercept of 1.2324, co-efficient of 1.6284 and p-value of $0.790>0.05$. Based on p-value, we accept the hypothesis that there is no significant relationship between bonuses and enterprise value. The negative co-efficient indicate that an increase in bonuses reduces the enterprise value of the firm. The determination co-efficient is 1.2324 which implies that the variation in bonuses explains $12 \%$ of the variation in enterprise value of the firm.

HO5: There is no relation significant between Bonuses paid and Market capitalization?

From the Hausmann test result on table 4.5 , p-value is $0.829>0.05$. We accept the assumption that random effect model is more appropriate in determining the relationship between bonuses and market capitalization. Therefore, we adopt Random effect model (REM) in assessing the relationship between bonuses (BON) and market capitalization. From regression of BON on MCAP result showed an intercept of 27.8830 and co-efficient -18.1858 and p-value of $0.002<0.05$. Based on p-value obtained, we reject the hypothesis that there is no significant relationship between bonuses and market capitalization. This implies that bonuses significantly negatively impact market capitalization. The negative co-efficient indicate that an increase in bonuses reduces market capitalization value of the firm. The determination co-efficient is 27.8830 which implies that the variation in profit sharing explains $28 \%$ of the variation in market capitalization as a measure of firm value.

\section{HO6: There is no significant relationship between Bonuses and Price to book value}

From the Hausmann test result on table4.5, p-value is $0.7125>0.05$. We accept the assumption that random effect model is more appropriate in assessing the relationship between profit sharing and enterprise value. Therefore, we 
adopt Random effect model (REM) in establishing the relationship between bonuses (BON) and PBV. From table 4.5, regression of BON on PBV showed an intercept of 0.8673 and co-efficient 21.8507 and P-value 0.507 >0.05. Based on p-value, we accept the hypothesis that there is no significant relationship between bonuses and PBV. This implies that bonuses do not significantly impacts PBV value. The negative co-efficient indicate that an increase in profit sharing reduces PBV. The determination co-efficient is 0.87 which implies that the variation in profit sharing explains $8 \%$ of the variation in PBV.

\subsection{Discussion of Findings}

The goal of the research was to examine whether performance driven compensation affects firm value. Our result show that profit sharing and bonus do not significantly relate with enterprise value, profit sharing does not relate significantly with market capitalization while bonus does not relate significantly with price to book value. Conversely bonus relates significantly with market capitalization while profit sharing relates significantly with Price to book value. The implication of our findings is that performance-based pay does not correlate with firm value. The reason could be adduced that market value of equity are driven by external factors to the firm and market conditions and perception differs significantly across industries. Size of the firm, efficiency, tangibility, dividend, ownership structure, market signals, timeliness and nature of reporting including quality of reports impact firm value.

Very limited literature tries to examine performance-based compensation across board as most empirically study is focused on earnings management and executive compensation and firm value. Our study deviates from the status quo and focuses on compensation from all strata of employees across the firm and tries to look at compensation as a motivational tool to high performance which enhances firm value.

Our study is a departure from Byun, Kim \& shin (2009) which found that performance-based compensation of Korean firms positively and significantly relates with Tobin Q as a measure of firm value. Also, they concluded that performance-based compensation enhances firm value through sales maximization. While it is natural that compensation is based on sales growth, there is no a priori reason why compensation cannot be based on improvement in profitability and productivity enhanced sales growth. Our study on the other hand found an insignificant relationship of performance base compensation with firm value. The proxy of our study bonus correlate significantly and negatively with maximization capitalization while profit sharing correlate significantly and negatively with price to book value. The implication of this negative association is also a departure from the findings of Byun, Kim \& shin (2009) which found a positive association of performance driven compensation with firm value. Secondly, it draws the attention of the researcher that the yardstick for measuring firm value could have an impact on result and therefore the interpretation of findings should be made with caution.

Negating our findings of no significant relationship between performance base compensation and firm value are studies from Rayton (1999), Ang \& Fatemi (1995), Blanchflower, Oswald, \& Sanfey (1996) and Smith \& Watts (1992). Rayton (1999) examines the link between pay and market performance and finds that for an average employee in USA doubling of firm value eventually leads to a 10 percent increase in pay. From a different perspective, average employees eventually receive increases in pay equal to approximately 4.1 percent of increases in firm value suggesting a positive relationship of pay performance with firm value. Ang \& Fatemi (1995) find a performance elasticity of 0.1 for UK firms and Blanchflower, Oswald, \& Sanfey (1996) find a performance elasticity of 0.08 firms in USA both suggesting significant positive association of pay for performance with firm value. Smith \& Watts (1992) observed positive relation of firm growth and incentive pay.

It is the believe that performance-based compensation system is effective when the income effect of the employees' efforts is high, when employees have relatively low risk-aversion, when performance can be accurately measured, and when the probability of employee productivity improvement is high. Therefore, such a system cannot be effectively applied to all firms with certainty in a country with weak institutions, poor monitoring and ineffective labor laws, these external factors may interplay to impact on our results.

Loan loss provisioning due to credit losses is a major factor that impacts on financial performance of banks. It is believed that any factor that impacts negatively on earnings mitigate firm value and shareholders wealth. The impact of loan loss on firm value is considered in this study. Loan loss provisioning from the study indicates a negative insignificant impact on PBV and Market capitalization (MCAP). Conversely it has a negative significant impact on Enterprise value (ENV) implying that increase in loan provisioning significantly reduces enterprise value.

Liquidity is essential to the survival of a firm and is a necessity for satisfying firm obligations. It is expected that higher level of liquidity ties down funds for investment and therefore there is a trade-off between liquidity and investment. Prior studies on relationship between liquidity and firm value produces mix result. While some studies found positive correlation, others found negative association and yet some found no correlation. Dui, Wu \& Liang (2016) in a study of China firms observed that liquidity significantly positively correlate with firm value implying that higher level of liquidity increases firm value. The authors further find that corporate liquidity also has diseconomies of scale. Excess corporate liquidity may adversely affect market value of large firms. According to 
Rizki, Mochammad \& Mangesli (2018) liquidity has positive and significant effects on firm value. Aisyah (2014) in her research states that liquidity has a positive and significant effect on firm value. The results of the study are also supported by the results of research from Nugroho (2014) which states that liquidity has a positive and significant effect on firm value. Mahendra Dj et al. (2012) found that liquidity is not significant positive effect on firm value. Timbuleng et al. (2015) found that liquidity does not affect Firm Value. Massie et al. (2018) found that liquidity significant positive effect on firm value. This suggests that the effect of liquidity on Firm Value is still varied. Our study departs from the above study as liquidity insignificantly correlate with PBV and ENV. On the other hand, it significantly negatively relates with market capitalization. The reason for the latter is not farfetched as increase liquidity constrain funds for investment mitigating the earnings potential of the firm hence low return to shareholders.

\subsection{Conclusion}

The focus of this study was to investigate the relationship of performance-based compensation on firm value of banks in Nigeria under panel data framework using secondary data spanning from 2012 to 2017. Our empirical outcome provides evidence that explanatory power of bonus and profit sharing relate with firm value. Consistent with prior study, this study measure firm value using PBV, Market capitalization and Enterprise value. Contrary to expectation, we found no significant relationship of profit sharing on enterprise value and market capitalization and no significant relationship of bonuses on Enterprise value and PBV. The negative co-efficient of profit sharing with Enterprise value indicate that an increase in profit sharing insignificantly reduces the Enterprise value of the firm. Conversely, Profit sharing have negative significant relation with PBV implying that an increase in PSH significantly reduces PBV. PSH positively insignificantly relate with MCAP implying that an increase in PSH increases MCAP although insignificantly.

Bonus on the other hand has negative insignificant relation with MCAP and PBV implying that an increase in bonus does not significantly change MCAP and PBV. In contrast, bonus has significant negative relation with Enterprise value implying that an increase in bonus significantly negatively reduce firm value.

The result interestingly indicates that value of banks in Nigeria are essentially driven by market conditions and factors external to compensation as pay does not motivate enough productivity to enhance value of banks in Nigeria. The reason is not far fetch. As enunciated by Herzeberg two factor theory certain factors are necessary for motivation in the work place but does not lead to long term satisfaction although its absence or non-existence in the work place will cause dissatisfaction and lead to sub-optimal productivity and low firm value. This is external from the job and relates to the job environment. Pay is expected to be competitive within same industry, appropriate and reasonable. Firm policies and administration should be flexible, fair, equitable, good physical working conditions such as Safety in the work place, clean and hygienic work place, and functional equipment encourage good interpersonal relation amongst employees, peers, superiors and subordinates. Employees should be offered job security. Herzberg further postulated that motivational factors otherwise referred to as satisfiers provide positive satisfaction and motivate employees to superior performance and goal accomplishment. This include recognition, Sense of achievement, Growth and promotional opportunities, Responsibility and Meaningfulness of the work. From Herzberg two factor theory perspectives, our result of a negative insignificant association of pay with firm value indicates absence of motivators amongst firms of study. This may be because of delayed promotion, job may not be enriched and meaningful, long hours of work, poor job security and poor job environment. Secondly, the Nigerian banking sector itself does not offer job security as many banks retrench yearly, there is delayed promotion in most of the banks that discourages commitment and long-term goal. There is also the issue of low compensation- earnings ratio in banks which may serve as a disincentive to high productivity hence the negative relation of pay and firm value. The negative association of the variables of study can also be explained in terms of Maslow's Theory.

Theoretically it could be explained that the negative association is a fall out of management of banks failure to satisfy psychological, safety needs and social needs of staff. The psychological needs by offering appropriate salaries to acquire basic needs of life, breaks, vacation and lunch. The safety needs to staff by providing job security, retirement benefits scheme to prevent labor turnover, safe and clean work environment. Nigerian banks are noted to have the highest turnover of staff in Sub-saharan Africa as many employees are laid off every year thereby eroding job security. Many of the employees work long hours without over time benefits and vacation. There is also the lack of satisfaction of social needs of employees. Social events that encourage bonding an interpersonal relationship are lacking in most Nigerian Banks as leisure and recreational support is only offered to management staff. Esteem needs of staff are sacrificed through nepotism, tribalism, delayed promotion and failure to align challenging jobs to requisite skills. Management positions are earned through connections rather than skills. These vagaries serve as disincentives to higher performance hence the negative relation of employee compensation to firm value. In sum our perspective agrees with the 


\subsection{Recommendations}

From the findings above, the researcher recommends as follows:

1. Management of banks in Nigeria should offer employees recognition for work well done, Sense of achievement, Growth and promotional opportunities.

2. Appointments to position of authority should be merit driven and based on the right skill set

3. Recreational facilities should be across the different strata of employees and not limited to management staff

4. Improvement on compensation-earnings ratio by offering appropriate salaries commensurate with efforts.

5. Job enrichment and appropriate work environment

6. Job security and safety.

7. Work life balance by avoiding long hours of work and monitoring to ensure supervisors allow staff to go on vacation when due.

8. Praise and recognition which are non-monetary can massage the ego of employees and motivate for higher productivity.

In summary, an appropriate compensation system, governance mechanisms, job security and good environment, job enrichment, promotions, work life balance, recreational facilities and fairness in the work place will assist banks in Nigeria in motivating staff and increasing productivity thereby enhancing shareholders wealth and firm value.

\subsection{Implications for Theory, Policy and Practice in Nigeria}

The outcome of the study confirms that Bonus and profit sharing as compensation does not increase firm value In Nigeria Banks as these variables are negatively related to firm value. The implication of these findings is that high productivity is achieved through the satisfaction of employees physiological, social and esteemed needs as postulated by Maslow. This are achieved via non- financial rewards.

Furthermore, our study conforms with the two-factor theory postulated by Hertzberg's that certain factors apart from pay motivate employees to higher productivity, the absence of which causes dissatisfaction. These include a congenial working environment and additional benefits motivate employees and are needed to keep employees happy. The lack of these factors makes the employee lose focus and drive and hence the lack of "hygiene" makes it difficult for the employee to continue. Herzberg also suggested that Recognition, sense of achievement, growth and promotional opportunities and meaningfulness of work motivate employees to higher productivity and firm value and not compensation alone suggesting that high pay not accompanied with other ingredients will not increase firm value

The results from this study have important policy implications. First, the negative relation of compensation to performance requires that policy makers and management should ensure the creation of job security, good job environment, job enrichment, safety, recognition, reward in addition to pay. However, the pay apart from being competitive should include non-monetary rewards to satisfy psychological needs which effectively motivates.

\subsection{Suggestions for Future Research}

Research findings provide valuable insights to stakeholders. The study also provides veritable opportunities to further research as stated below:

1)The study of compensation can be enriched by further studies on the effect of Firm performance on Firm value.

2) A comparative study of Compensation, Performance and firm Value

3) Equity based compensation and firm value

4) This study can be extended to a capital-intensive industry as the current study is on a regulated industry the outcome of which may be impacted by the nature of the Industry and high regulation.

This study only examined the banking industry of the Nigerian economy. However, future research could evaluate other sectors of the Nigerian economy adopting similar methodology.

\subsection{Contribution to Knowledge}

1)The study contributes to existing literature in three ways: First, the findings serve as a reminder to banks in Nigeria to look inward and design a policy that will ensure job enrichment, security and adequate compensation for employees.

2) It serves as a wakeup call on bank management that productivity and increased firm value can be achieved through fair, articulate and well design compensation plan and reward system.

3) The study contributes to knowledge through the formulation of the underlying econometric model

\section{References}

Aggarwal D, Padhan PC (2017), 'Impact of Capital Structure on Firm Value: Evidence from Indian Hospitality Industry'. Theoretical Economics Letters (7), 982-1000.

Amihud Y \& Mendelson H. (1986), 'Asset pricing and the bid-ask spread. Journal of Financial Economics"', (2): 
223-249.

Ang. J. and Ali Fatemi, A. (1995), 'The Alignment of Management and Employee Compensations:

The Case of U.K. Firms.' Journal of Multinational Financial Management 5, 73-85.

Azhagaiah, R., \&Priya, S. N. (2008), 'The impact of dividend policy on shareholders' wealth'. International Research Journal of Finance and Economics, 20, 180 - 187

Banz R W. (1981), 'The relationship between return and market value of common stocks". Journal of financial Economics, (1): 3-18.

Bastors, J.A., \& Ramalho J.J. (2010, September). CEMAPRE - the Centre for Applied Mathematics and Economics. Retrieved April 01,2019, from ISEG-Technical University of Lisbon: http://evunix.uevora.pt/ jsr/

Baugess, S., Slovin, M., and Sushka, M. (2012), 'Large shareholder diversification, corporate risk taking, and the benefits of changing to differential voting rights'. Journal of Banking and Finance, 36, 1244-1253.

Brickley, J., Bhagat, S. and Lease, R. (1985). The Impact of Long-Range Managerial Compensation Plans on Shareholder Wealth, Journal of Accounting and Economics, 7, 115-129.

Black, B.S.,Jang, H and Kim, W (2006), 'Does Corporate Governance Predict Firms' Market Values? Evidence from Korea", Journal of Law, Economics and Organization 22, 366-413.

Blanchflower,D Oswald,A and Sanfey, P (1996), 'Wages, Profits, and Rent-Sharing'. The Quarterly Journal of Economics, Volume 111, Issue 1, February 1996, Pages 227-251, https://doi.org/10.2307/2946663Brandenburger A, Stuart JHW (1996), 'Value-Based Business Strategy'. The Journal of Economics and Management Strategy 5: 5-24.

Brown JR \& B C Peterson. (2011), 'Cash Holdings and R\&D Smoothing', Journal of Corporate Finance, (17): 694-709.

Byun, D., Kim, J. and Shin,J (2009), 'The Effects of Deferred Compensation and Performance-based Compensation on Firm Value', Asia-Pacific Journal of Accounting \& Economics 16 (2009) 49-68

Cadsby, C., Song, F., \& Tapon, F. (2007), 'Sorting and Incentive Effects of Pay for Performance: An Experimental Investigation', Academy of Management Journal, 50(2), 387-405.

Chen, H. and Leng, F. (2004), 'Pay-Performance Sensitivity in a Heterogeneous Managerial Labor Market', Journal of Management Accounting Research, 16, 19-34.

Core, J. and Guay, W. (2001), 'Stock Option Plans for Non-Executive Employees', Journal of Financial Economics, 60, 253-267.

Dhanani, A. (2005). 'Corporate dividend policy: The views of British financial managers'. Journal of Business Finance and Accounting, 37(7) and (8), 1625-1672

Dittmar A \& Mahrt-Smith J. (2005), 'Corporate governance and the value of cash holdings'. Journal of Financial Economics, 83(3): 599-634.

Dui, J .Wu,F. and Liang (2016), 'Corporate liquidity and firm value: evidence from China's listed firms'. SHS Web of Conferences 24,0103 (2016). DOI: 10.1051/published by EDP Sciences,

Guth W. D. (1990), 'Guest editor's introduction corporate entrepreneurship'’. Strategic Management Journal, (11): $5-15$.

Holmstrom, Tirole. (2000), 'Liquidity and risk management'’. Journal of Money. Credit and Banking, (32), 295319.

Peterson, P. (1999), ‘Analysis of Financial Statements’. New York: Wiley. p. 92. ISBN 1-883249-59-7.

Zhou, P. and Ruland, W. (2006). Dividend payout and future earnings growth. Financial Analysts Journal, 62(3), $58-69$.

Houston, J., Lin, C., Lin, P., and Ma, Y. (2010), 'Creditor rights, information sharing, and bank risk taking'. Journal of Financial Economics, 96, 485-512. http://dx.doi.org/10.15414/isd2016.s5.07 377

Holmstrom, Tirole. (2000), 'Liquidity and risk management. Journal of Money. Credit and Banking', (32): 295319.

Jonathan P. (2003), 'The capital structure implications of pursuing a strategy of innovation". Strategy Management Journal, (3): 5-9.

John, K., Litov, K., andYeung, B. (2008), ‘Corporate governance and risk-taking’’. Journal of Finance, 63, 16791728

Kim C S \& Sherman A E. (2012), 'The determinants of corporate liquidity: Theory and evidence'. Social Science Electronic Publishing, 33(3): 335- 359.

Larker, D., (1983), 'The Association Between Performance Plan Adoption and Corporate Capital Investment', Journal of Accounting and Economics, 5, 3-30.

Lazear, E. (2004), 'Output-Based Pay: Incentives, retention or Sorting?'’ Research in Labor Economics, 23, 1-25

Louis.Cadsby, C., F. Song, and F. Tapon. (2007), 'Sorting and incentive effects of pay for performance: An experimental investigation'. Academy of Management Journal 50 (2): 387-405

Mahendra DJ, A., Artini, LGS, and Suarjaya, AG (2012), 'The influence of the financial performance of the 
company's value in manufacturing companies in Indonesia Stock Exchange'. Matrix: Journal of Management, Business Strategy and Entrepreneurship.

Martini, PD (2015), 'Influence Policy Against Debt and Profitability Firm Value: Dividend Policy as moderating variables"'. Journal of Science and Accounting Research, 3 (2).

Massie, JV, Tommy, P., \& Koleangan, RA (2018), 'A financial analysis of Firm Value (Studies in consumer goods companies are food and beverages sub-sector listed on the Stock Exchange in 2011-2016”. EMBA Journal: Journal of Economic Research, Management, Business and Accounting, 5 (3).

Nugroho, Asih Suko. (2004), '’Analisis Faktor-faktor yang Mempengaruhi Struktur Modal

Perusahaan Properti yang Go Public di Bursa Efek Jakarta Untuk Periode Tahun 1994- 2004". Tesis. Magister Manajemen Pascasarjana. Universitas Diponegoro.

Ozkan A \& Ozkan N. (2004), 'Corporate cash holdings: An empirical investigation of UK companies'. Journal of Banking \& Finance, 28(9): 2103-2134.

Rayton ,B. (1999). Firm Performance and Compensation Structure:

Performance Elasticities of Average Employee Compensation. University of Bath School of Management Working Paper Series

Rayton. B (1995). The CEO is Not the Only Employee of the Firm: An Empirical Investigation of Firm-Level Pay-Performance Relationships. Ph.D. dissertation. Washington University - St.

Rayton, B. (1995). The CEO is Not the Only Employee of the Firm: An Empirical Investigation of Firm-Level Pay-Performance Relationships. Ph.D. dissertation. Washington University - St. Louis.

Rayton, B. (1997). Rent-Sharing or Incentives? Estimating the Residual Claim of Average Employees. Applied Economics Letters 4, 725-728.

Rayton, B. (1999). The Size of Employee Stakeholding in Large UK Corporations. Managerial and Decision Economics 20, 259-266.

Rizki, z,Mohammad, D and Mangesti, R.(2018), 'The effect of Profitability,Liquidity on Capital Structure and Firm Value'. A study of Property and Real Estate Companies listed on Indonesia Stock Exchange 20132015. Eurasia: Economics \& Business, 2(8), February 2018. DOI https://doi.org/10.18551/econeurasia.201802

Smith, C. and Watts, R. (1982), 'Incentive and Tax Effects of Executive Compensation Plans', Australian Journal of Management, 7, 139-157.

Tehranian, H. and Waegelein, J. (1985), 'Market Reaction to Short-term Executive Compensation Plan Adoption', Journal of Accounting and Economics, 7, 131-144.

Timbuleng, F., Nangoy, SC, \&Saerang, IS (2015), 'The effect of factors, liquidity, leverage, NPM, and ROI on Firm Value (Study on Consumer Goods Companies Listed on the Indonesia Stock Stock Period 2010-2013)', EMBA Journal: Journal of Economic Research, Management, Business and Accounting, 3 (2).

Uwuigbe, O., Fagbemi, T.O. and Anusiem, U.F. (2012), "The effects of audit committee and ownership structure on income smoothening in Nigeria", Research Journal of Finance and Accounting, vol. 3, issue: 4, 26-33.

Waller, W. S. and Chow, C., (1985), 'The Self-Selection and Effort effects of Standard-Based Employment Contracts: A Framework and Some Empirical Evidence', The Accounting Review, 60(3), 458-476.

Wolfgang Drobetz \& Grüninger M C. (2007), 'Corporate cash holdings: Evidence from Switzerland', Financial Markets \& Portfolio Management, 21(3): 293-324. 